\title{
Application of Optimal Combined Microfertilizers of Boron, Molybdenum, and Copper Improves Root Tuber Yield Trait and Photosynthetic Response Characteristics in Pseudostellaria heterophylla
}

\author{
Yingli Ma and Tingting Yuan \\ Co-Innovation Center for Sustainable Forestry in Southern China, College \\ of Biology and the Environment, Nanjing Forestry University, Nanjing \\ 210037, China
}

\begin{abstract}
Tao Wang
Jiangsu Key Laboratory for the Research and Utilization of Plant Resources, Institute of Botany, Jiangsu Province and Chinese Academy of Sciences (Nanjing Botanical Garden Mem. Sun Yat-Sen), Nanjing 210014, China
\end{abstract}

Jiaxin Li, Zhongqiu Xu, Siqian Luo, and Yinfeng Xie

Co-Innovation Center for Sustainable Forestry in Southern China, College of Biology and the Environment, Nanjing Forestry University, Nanjing 210037, China

Additional index words. 3414 experimental design, B-Mo- $\mathrm{Cu}$, diurnal variation of photosynthesis, growth index, JIP test

Abstract. In the actual cultivation process, blind fertilizer application was widespread, resulting in a serious decline in the yield of Pseudostellaria heterophylla. We used the 3414 fertilizer experiment design to study the effects of combined Boron (B), Molybdenum (Mo), and Copper $(\mathrm{Cu})$ on the growth indexes, diurnal changes of photosynthesis, and rapid fluorescence induction dynamics in $P$. heterophylla. Our results show that the optimal combination of $\mathrm{B}, \mathrm{Mo}$, and $\mathrm{Cu}$ simultaneously promoted the growth of underground and aboveground parts, and significantly improved the quality of single root tuber and yield per unit area. The best combination was treatment 9 (T9= B, $1 \mathrm{~g} / \mathrm{L} ; \mathrm{Mo}, 0.08 \mathrm{~g} / \mathrm{L} ; \mathrm{Cu}, 0.05 \mathrm{~g} / \mathrm{L}$ ), and resulted in a $35.1 \%$ increase in yield per unit area compared with the control group (T1). Although the optimal combined application of microfertilizers did not change the bimodal trend of diurnal variation of photosynthesis, it effectively increased the daily average, peak, and valley values of the photosynthetic rate by alleviating the nonstomatal limitation and the photosynthetic midday depression. Pseudostellaria heterophylla leaves showed greater photochemical activity and less photoinhibition of photosystem II in T9. Major effects were that it helped protect the activity of the oxygen-evolving complex to reduce the oxidative damage of chloroplasts and prevent the dissociation of thylakoid. The microfertilizer application also enhanced the electron receiving ability of the $Q_{B}$ and plastoquinone (PQ) electronic pools, thereby increasing the ability of electron transfer from $Q_{A}$ to $Q_{B}$. The number of reaction centers per unit area was promoted notably by the fertilization treatment.

Pseudostellaria heterophylla, in the Caryophyllaceae family, is a perennial herb that is well-known in China for its medicinal value. Its root tuber has medicinal and therapeutic functions such as invigorating the Qi and spleen, moisturizing the lungs, and relieving cough, and it has antihuman immunodeficiency virus infection, antidiabetic, and anticancer properties, among others (Sun et al., 2010; Yang et al., 2020a). With the increase in clinical demand and the development of functional foods for $P$. heterophylla, its market demand has broadened steadily year by year, and its artificial cultivation areas have also expanded as well. As with other medicinal plant production, fertilizer application has become an important measure to improve the growth characteristics and yield of $P$. heterophylla. In recent years, the amount of N, P, K, and other elements of chemical fertilizer were high, and the use of organic fertilizer was very low in production.
The total biological output per unit area of arable land has continued to increase. However, the trace elements in soil were continuously consumed, thereby restricting the improvement of crop yield and nutrient quality (Verbruggen and Hermans, 2013).

Boron, $\mathrm{Mo}$, and $\mathrm{Cu}$ are essential elements for plant growth and development (Wu et al., 2017a). These elements play important roles in regulating plant growth and development, especially in photosynthesis and other metabolic processes, and in organic matter transportation and distribution, and have been verified in many plants (Macedo et al., 2021). For example, one study showed that spraying B fertilizer on the leaves of Raphanus sativus effectively increased the chlorophyll content, enhanced photosynthesis, and promoted sugar metabolism during the flowering process (Wang et al., 2018). In Beta vulgaris, B fertilizer application outside the roots effectively improved its leaf performance and promoted root tuber expansion as well as its sugar content (Song et al., 2019). In wheat, Mo fertilizer application significantly increased the chlorophyll content, delayed the senescence, and prolonged the functional period of leaves, thereby improving the photosynthetic intensity, capacity, and time, and increasing the 1000 grain weight and yield of wheat ( $\mathrm{Li}, 2019)$. In rice, $\mathrm{Cu}$ fertilizer application promoted the growth and increased yield of rice significantly (Mo, 2018). These results indicate that the application of B, $\mathrm{Mo}$, and $\mathrm{Cu}$ alone could regulate the growth and development of plants significantly. Does their combination have a synergistic effect? To verify this scientific hypothesis, we examined B, Mo, and $\mathrm{Cu}$ combination fertilization to verify the synergistic effect between different microfertilizers and find the best fertilization scheme.

In the traditional cultivation and production of $P$. heterophylla, fertilizer application was often blind. People paid more attention to $\mathrm{N}-\mathrm{P}-\mathrm{K}$ fertilizers and ignored the use of microelement fertilizers. This led to a surplus of N-P-K and a depletion of microelements in the soil. Such practice reduced the fertilizer utilization rate, polluted the environment, and seriously affected the yield of $P$. heterophylla (Wu et al., 2017b). More N-P-K fertilizers were applied in the production practice of $P$. heterophylla (Zhang et al., 2015a), but there were few reports on the effects of the combined application of microfertilizers on the yield and photosynthetic characteristics of $P$. heterophylla. Therefore, we evaluated the effects of microelement fertilizers, particularly the combination of $\mathrm{B}, \mathrm{Mo}$, and $\mathrm{Cu}$, on root yield of $P$. heterophylla. On the basis of optimizing the combination of $\mathrm{B}, \mathrm{Mo}$, and $\mathrm{Cu}$ for fertilizer application, the photosynthetic response mechanism of increased production was investigated further through the diurnal variation of photosynthesis and the chlorophyll fluorescence kinetics. Accordingly, results of this study provided a theoretical basis and application for the optimal ratio of $\mathrm{B}, \mathrm{Mo}$, and $\mathrm{Cu}$ as foliar fertilizers toward achieving high-efficiency cultivation in P. heterophylla. 


\section{Materials and Methods}

Experimental field site. The experimental site was located at the Xiashu forest farm of Nanjing Forestry University (lat. $31^{\circ} 59 \mathrm{~N}^{\prime}$, long. $119^{\circ} \mathrm{E}^{\prime}$ ), Jiangsu Province, China, and the experiments were conducted between Nov. 2018 and June 2019. The soil type was yellow-brown soil with an organic matter content of $7.39 \mathrm{~g} \cdot \mathrm{kg}^{-1}$, and total $\mathrm{N}$ and $\mathrm{P}$ contents of 0.704 and $0.146 \mathrm{~g} \cdot \mathrm{kg}^{-1}$, respectively, and available $\mathrm{P}$ and $\mathrm{K}$ contents of 12.5 and $103.7 \mathrm{mg} \cdot \mathrm{kg}^{-1}$, respectively (Ma et al., 2017). Effective $\mathrm{B}, \mathrm{Mo}$, and $\mathrm{Cu}$ was $0.28,0.1$, and $0.99 \mathrm{mg} \cdot \mathrm{kg}^{-1}$, respectively.

Plant material and experimental design. The $P$. heterophylla seeds used in the study were provided by the forest station in Zherong County, Fujian Province. Strong, disease-free, and harmless seedlings of $P$. heterophylla were selected for cultivation. After soil preparation, ridges were constructed measuring $1600 \mathrm{~cm}$ in length, $100 \mathrm{~cm}$ in width, and $25 \mathrm{~cm}$ in height. Next, five furrows of $\approx 12 \mathrm{~cm}$ in depth with a row spacing of $15 \mathrm{~cm}$ were created. Drill sowing was performed at $100 \mathrm{~g} \cdot \mathrm{m}^{-2}$, allowing a 4$\mathrm{cm}$ spacing between plants.

The 3414 fertilizer application experiment design was adopted-namely, $\mathrm{B}$ fertilizer $\left(\mathrm{Na}_{2} \mathrm{~B}_{4} \mathrm{O}_{7} \cdot 10 \mathrm{H}_{2} \mathrm{O}\right)$, Mo fertilizer $\left(\mathrm{H}_{8} \mathrm{MoN}_{2} \mathrm{O}_{4}\right)$, and $\mathrm{Cu}$ fertilizer $\left(\mathrm{CuSO}_{4} \cdot 5 \mathrm{H}_{2} \mathrm{O}\right)$ : three factors and four levels with a total of 14 treatments. Three replicates were set for each treatment, and the experimental plot area was $2 \mathrm{~m}^{2}(2 \times 1 \mathrm{~m})$. Tables 1 and 2 show the levels of microelement fertilizer application factors and the specific fertilizer application design, respectively. Treatment 1 (T1) served as control group (equal amount of distilled water). The trace element solution was sprayed on leaves twice every $10 \mathrm{~d}$. The spraying time was in April and before 0900 $\mathrm{HR}$ on the day, and the spraying dose was based on leaf dripping. During the experiment, water and other environmental conditions remained consistent with standard field conditions.

Determination of growth indexes. seedling height and root length were measured with a

Received for publication 22 Feb. 2021. Accepted for publication 10 May. 2021.

Published online 25 August 2021.

We thank LetPub (www.letpub.com) for linguistic assistance during the preparation of this manuscript.

This work was supported by the Postgraduate Research \& Practice Innovation Program of Jiangsu Province, the Priority Academic Program Development of Jiangsu Higher Education Institutions, the Doctorate Fellowship Foundation of Nanjing Forestry University, and Training Programs of Innovation and Entrepreneurship for Undergraduates of Nanjing Forestry University (201410298001Z).

Y.L.M. and T.T.Y. conceived and designed the experiments. T.W., J.X.L., Z.Q.X., and S.Q.L. performed the experiments. Y.L.M. analyzed the data and wrote the manuscript. Y.F.X. revised and approved the final manuscript. All authors reviewed the manuscript.

Y.X. is the corresponding author. E-mail: xxyyff_njfu@163.com.

This is an open access article distributed under the CC BY-NC-ND license (https://creativecommons. org/licenses/by-nc-nd/4.0/).
Table 1. The levels of microelement fertilization Boron (B), Molybdenum (Mo), and Copper $(\mathrm{Cu})$ factors.

\begin{tabular}{lccc}
\hline Factor levels & $\mathrm{B}\left(\mathrm{g} \cdot \mathrm{L}^{-1}\right)$ & $\mathrm{Mo}\left(\mathrm{g} \cdot \mathrm{L}^{-1}\right)$ & $\mathrm{Cu}\left(\mathrm{g} \cdot \mathrm{L}^{-1}\right)$ \\
\hline 0 & 0 & 0 & 0 \\
1 & 0.50 & 0.04 & 0.05 \\
2 & 1.00 & 0.08 & 0.10 \\
3 & 1.50 & 0.12 & 0.15 \\
\hline
\end{tabular}

Stanley 30-6-165 M tape (Stanley, Nanjing, China), whereas the ground and root diameters were measured with a 0 - to $300-\mathrm{mm}$ electronic vernier caliper (Deli, Nanjing, China). When the aboveground part of $P$. heterophylla was completely withered and yellow, all the samples were collected from each plot. The aboveground part was removed, and the underground part was washed and dried by airing. The fresh weight of root tubers was recorded and the yield was calculated by the mass of root tubers per unit area, with three replicates. Seedling height and ground diameter were measured with six replicates before harvest, whereas root length, root diameter, and yield per unit area were measured after harvest. Twenty root tubers were selected randomly to measure the root length and root diameter.

Determination of diurnal variation of photosynthesis. The diurnal variation of photosynthesis of $P$. heterophylla leaves was quantified by the standard leaf chamber of an Li-6400R portable photosynthesis system (Li-COR Bio-sciences, Lincoln, NE) on a sunny day in mid-May. Measurements were conducted in a $6-\mathrm{cm}^{2}$ leaf chamber under the condition of an open gas system, uncontrolled ambient $\mathrm{CO}_{2}$ concentration and air temperature, and natural light. Six leaves that were deemed healthy, functional, and of a similar size were identified in each treatment and measured. Measurements were taken at 2-h intervals from 0700 to $1700 \mathrm{HR}$ at the same position. The diurnal changes in net photosynthetic rate $\left(\mathrm{P}_{\mathrm{n}}\right)$, stomatal conductance $\left(g_{\mathrm{S}}\right)$, intercellular $\mathrm{CO}_{2}$ concentration $\left(C_{\mathrm{i}}\right)$, and transpiration rate $\left(T_{\mathrm{r}}\right)$ were measured simultaneously using the same method. The data were recorded when the rate of $\mathrm{CO}_{2}$ uptake had stabilized.

Table 2. Boron (B), Molybdenum (Mo), and Copper (Cu) application scheme.

\begin{tabular}{|c|c|c|c|c|c|c|c|}
\hline \multirow[b]{2}{*}{ Treatment no. } & \multirow[b]{2}{*}{ Treatment combination } & \multicolumn{3}{|c|}{ Fertilizer level } & \multicolumn{3}{|c|}{ Fertilizer dose $\left(\mathrm{g} \cdot \mathrm{L}^{-1}\right)$} \\
\hline & & $\mathrm{B}$ & Mo & $\mathrm{Cu}$ & $\mathrm{B}$ & Mo & $\mathrm{Cu}$ \\
\hline 1 & $\mathrm{~B}_{0} \mathrm{Mo}_{0} \mathrm{Cu}_{0}$ & 0 & 0 & 0 & 0 & 0 & 0 \\
\hline 2 & $\mathrm{~B}_{0} \mathrm{Mo}_{2} \mathrm{Cu}_{2}$ & 0 & 2 & 2 & 0 & 0.08 & 0.10 \\
\hline 3 & $\mathrm{~B}_{1} \mathrm{Mo}_{2} \mathrm{Cu}_{2}$ & 1 & 2 & 2 & 0.50 & 0.08 & 0.10 \\
\hline 4 & $\mathrm{~B}_{2} \mathrm{Mo}_{0} \mathrm{Cu}_{2}$ & 2 & 0 & 2 & 1 & 0 & 0.10 \\
\hline 5 & $\mathrm{~B}_{2} \mathrm{Mo}_{1} \mathrm{Cu}_{2}$ & 2 & 1 & 2 & 1 & 0.04 & 0.10 \\
\hline 6 & $\mathrm{~B}_{2} \mathrm{Mo}_{2} \mathrm{Cu}_{2}$ & 2 & 2 & 2 & 1 & 0.08 & 0.10 \\
\hline 7 & $\mathrm{~B}_{2} \mathrm{Mo}_{3} \mathrm{Cu}_{2}$ & 2 & 3 & 2 & 1 & 0.12 & 0.10 \\
\hline 8 & $\mathrm{~B}_{2} \mathrm{Mo}_{2} \mathrm{Cu}_{0}$ & 2 & 2 & 0 & 1 & 0.08 & 0 \\
\hline 9 & $\mathrm{~B}_{2} \mathrm{Mo}_{2} \mathrm{Cu}_{1}$ & 2 & 2 & 1 & 1 & 0.08 & 0.05 \\
\hline 10 & $\mathrm{~B}_{2} \mathrm{Mo}_{2} \mathrm{Cu}_{3}$ & 2 & 2 & 3 & 1 & 0.08 & 0.15 \\
\hline 11 & $\mathrm{~B}_{3} \mathrm{Mo}_{2} \mathrm{Cu}_{2}$ & 3 & 2 & 2 & 1.50 & 0.08 & 0.10 \\
\hline 12 & $\mathrm{~B}_{1} \mathrm{Mo}_{1} \mathrm{Cu}_{2}$ & 1 & 1 & 2 & 0.50 & 0.04 & 0.10 \\
\hline 13 & $\mathrm{~B}_{1} \mathrm{Mo}_{2} \mathrm{Cu}_{1}$ & 1 & 2 & 1 & 0.50 & 0.08 & 0.05 \\
\hline 14 & $\mathrm{~B}_{2} \mathrm{Mo}_{1} \mathrm{Cu}_{1}$ & 2 & 1 & 1 & 1 & 0.04 & 0.05 \\
\hline
\end{tabular}

Determination of fast chlorophyll fluorescence induction kinetic curve. The parameters of chlorophyll fluorescence induction kinetics were measured using a continuous excitation fluorometer (Handy-PEA; Hansatech, UK) in mid-May. The leaves were first adapted in the dark for $30 \mathrm{~min}$, then exposed to saturated, pulsed light. The fast fluorescence kinetic induction curves (OJIP) were measured with the HandyPEA and analyzed using the analysis of fast fluorescence kinetic induction curve (JIP-test) (Strasser, 1997). Table 3 shows the parameters of chlorophyll fluorescence induction kinetics.

Statistical analysis. Data processing and statistics were done in Excel 2010 and SPSS 18.0 statistical software (Version 18.0; IBM Corp., Armonk, NY). Post hoc comparisons of means were evaluated using Duncan's new complex range method and were measured at the 5\% significance level.

\section{Results}

\section{Optimization of fertilizer amounts of B, $\mathrm{Mo}$, and $\mathrm{Cu}$ in $P$. heterophylla}

Table 4 shows the effects of the combined application of $\mathrm{B}, \mathrm{Mo}$, and $\mathrm{Cu}$ on seedling height, ground diameter, root length, root diameter, and yield per unit area of $P$. heterophylla in varying degrees. Of the 14 treatments, T9 $\left(\mathrm{B}_{2} \mathrm{Mo}_{2} \mathrm{Cu}_{1}\right)$ showed the best positive effect for growth indicators except seedling height. Compared with T1 (control, $\mathrm{B}_{0} \mathrm{Mo}_{0} \mathrm{Cu}_{0}$ ), T9 values for the growth indicators were increased by $16.48 \%, 10.10 \%$, $13.63 \%, 28.19 \%$, and $35.17 \%$, respectively. The results showed that the optimal combined application of $\mathrm{B}, \mathrm{Mo}$, and $\mathrm{Cu}$ influenced the growth of the aboveground and underground parts of $P$. heterophylla significantly and positively. The optimal B, Mo, and $\mathrm{Cu}$ combination not only increased the yield per unit area effectively of $P$. heterophylla root, but also promoted significantly the quality of the single root tuber (root length and diameter). 
Table 3. The parameters of chlorophyll fluorescence induction kinetics.

\begin{tabular}{|c|c|}
\hline $\mathrm{F}_{\mathrm{v}} / \mathrm{F}_{\mathrm{m}}$ & $\begin{array}{l}\text { maximum photochemical efficiency } \\
\text { of PSII }\end{array}$ \\
\hline $\mathrm{PI}_{\text {abs }}$ & photochemical performance index \\
\hline $\begin{array}{l}\varphi P 0 \\
\Psi_{0}\end{array}$ & $\begin{array}{l}\text { maximum quantum emciency or PSII } \\
\text { electron transfer efficiency }\end{array}$ \\
\hline$\varphi$ Eo & quantum yield of electron transfer \\
\hline$\varphi \mathrm{Do}$ & quantum ratio of heat dissipation \\
\hline $\mathrm{ABS} / \mathrm{RC}$ & $\begin{array}{l}\text { energies absorbed by the unit } \\
\text { reaction center }\end{array}$ \\
\hline $\mathrm{TRo} / \mathrm{RC}$ & $\begin{array}{l}\text { energies captured by the unit } \\
\text { reaction center }\end{array}$ \\
\hline $\mathrm{ETo} / \mathrm{RC}$ & $\begin{array}{l}\text { energies used for electron transfer } \\
\text { by the unit reaction center }\end{array}$ \\
\hline TRo/RC & $\begin{array}{l}\text { energies used for heat dissipation by } \\
\text { the unit reaction center }\end{array}$ \\
\hline $\mathrm{RC} / \mathrm{CSo}$ & density of reaction center \\
\hline$V_{L}$ & $\begin{array}{l}\mathrm{L} \text { point relative variable } \\
\text { fluorescence; } \mathrm{V}_{\mathrm{L}}=(\mathrm{Ft}-\mathrm{Fo}) / \\
\left(\mathrm{F}_{\mathrm{K}}-\mathrm{Fo}\right), \text { where } \mathrm{L} \text { is } 0.15 \mathrm{~ms}\end{array}$ \\
\hline $\mathrm{V}_{\mathrm{K}}$ & $\begin{array}{l}\mathrm{K} \text { point relative variable } \\
\text { fluorescence; } \mathrm{V}_{\mathrm{K}}=(\mathrm{Ft}-\mathrm{Fo}) / \\
\left(\mathrm{F}_{\mathrm{J}}-\mathrm{Fo}\right) \text {, where } \mathrm{K} \text { is } 0.3 \mathrm{~ms}\end{array}$ \\
\hline $\mathrm{V}_{\mathrm{J}}$ & $\begin{array}{l}\mathrm{J} \text { point relative variable } \\
\text { fluorescence; } \mathrm{V}_{\mathrm{J}}=(\mathrm{Ft}-\mathrm{Fo}) / \\
(\mathrm{Fm}-\mathrm{Fo}), \text { where } \mathrm{J} \text { is } 2 \mathrm{~ms}\end{array}$ \\
\hline$V_{I}$ & $\begin{array}{l}\text { I point relative variable } \\
\text { fluorescence; } V_{\mathrm{I}}=(\mathrm{Ft}-\mathrm{Fo}) / \\
(\mathrm{Fm}-\mathrm{Fo}) \text {, where } \mathrm{I} \text { is } 30 \mathrm{~ms}\end{array}$ \\
\hline
\end{tabular}

Effects of the combined application of $B$, $\mathrm{Mo}$, and $\mathrm{Cu}$ on the diurnal variation of photosynthesis in $\boldsymbol{P}$. heterophylla

To explore further the physiological mechanism of $P$. heterophylla treated with the $\mathrm{B}, \mathrm{Mo}$, and $\mathrm{Cu}$ combinational application from a photosynthetic perspective, the best treatment for increasing production (T9) and the control group (T1) were selected as materials to analyze further and compare the characteristics of the diurnal variation of photosynthesis and photosystem II (PSII) rapid fluorescence induction kinetics.

Environmental factors. The photosynthetic photon flux density was only $500 \mu \mathrm{mol} \cdot \mathrm{m}^{-2} \cdot \mathrm{s}^{-1}$ at $0700 \mathrm{HR}$. After $0700 \mathrm{HR}$, it rose significantly and peaked at $1500 \mu \mathrm{mol} \cdot \mathrm{m}^{-2} \cdot \mathrm{s}^{-1}$ around 1300 $\mathrm{HR}$, followed by a marked decrease thereafter, dropping to less than $600 \mu \mathrm{mol} \cdot \mathrm{m}^{-2} \cdot \mathrm{s}^{-1}$ at 1700 HR. The air temperature presented a single- peak curve, reaching its maximum value of $31.76^{\circ} \mathrm{C}$ at $1300 \mathrm{HR}$, and the average temperature was $27.03{ }^{\circ} \mathrm{C}$. Diurnal fluctuations in air relative humidity decreased over time, with a maximum value of $56 \%$ at $0700 \mathrm{HR}$ followed by a rapid decrease, dropping to $38 \%$ by 1300 $\mathrm{HR}$. The trend in ambient $\mathrm{CO}_{2}$ concentration was different from the other environmental factors. It vacillated between 407 and 413 $\mu \mathrm{mol} \cdot \mathrm{mol}^{-1}$ between sunrise and sunset.

Diurnal photosynthetic variation. Figure 1A shows that the $P$. heterophylla leaves in $\mathrm{T} 1$ had a bimodal response in $\mathrm{P}_{\mathrm{n}}$, displaying a discernable photosynthetic midday depression (1300 HR), with two peaks occurring at 0900 and 1500 HR, with the first peak being higher than the second. Compared with T1, T9 showed no change in bimodal pattern. However, the whole-day $\mathrm{P}_{\mathrm{n}}$ increased significantly, including the daily mean value $(65.55 \%)$, peak values $(51.80 \%, 107.76 \%)$, and valley value $(104.63 \%)(P<0.05)$, thereby effectively circumventing the photosynthetic midday depression experience.

Figure 1B-D showed that the daily variation trend in $g_{\mathrm{S}}$ in $P$. heterophylla was basically consistent with that of $\mathrm{P}_{\mathrm{n}}$. Both T1 and T9 showed double-peak changes. However, T9 increased significantly the daily mean value, peak value, and valley value of $g_{\mathrm{S}}$. The diurnal variation of $C_{\mathrm{i}}$ was contrary to that of $\mathrm{P}_{\mathrm{n}}$ and $g_{\mathrm{S}}$. In general, the change trend of $C_{\mathrm{i}}$ was the $\mathrm{W}$ type, and it showed a peak value during the photosynthetic midday depression. T9 reduced $C_{\mathrm{i}}$ significantly in the process of daily change, including daily mean, valley value, and peak value. The daily $T_{\mathrm{r}}$ profile showed a rapid increase to the daily maximum at midday (1300 HR) and then a gradual reduction in as the day proceeded to dusk. Moreover, T9 showed a pronounced positive influence on the whole-day $T_{\mathrm{r}}$ compared with $\mathrm{T} 1$.

\section{Effect of the combined application of B, $\mathrm{Mo}$, and $\mathrm{Cu}$ on the characteristics of rapid fluorescence induction kinetics}

PSII photochemical activity. Figure 2 shows that, compared with the control group (T1), the T9 fertilizer application increased the maximum photochemical efficiency $\left(\mathrm{F}_{\mathrm{v}}\right)$

Table 4. Effects of combined applications of Boron (B), Molybdenum (Mo), and Copper (Cu) on the growth indexes of $P$. heterophylla.

\begin{tabular}{llllll}
\hline No. & Seedling ht $(\mathrm{cm})$ & Ground diam $(\mathrm{mm})$ & Root length $(\mathrm{cm})$ & Root diam $(\mathrm{mm})$ & \multicolumn{1}{c}{ Yield $\left(\mathrm{g} \cdot \mathrm{m}^{-2}\right)$} \\
\hline 1 & $12.62 \pm 0.73 \mathrm{~d}$ & $1.98 \pm 0.07 \mathrm{~b}$ & $8.29 \pm 0.01 \mathrm{~d}$ & $5.64 \pm 0.28 \mathrm{ef}$ & $335.16 \pm 5.00 \mathrm{j}$ \\
2 & $12.75 \pm 0.53 \mathrm{~d}$ & $2.00 \pm 0.11 \mathrm{~b}$ & $8.47 \pm 0.10 \mathrm{~cd}$ & $6.04 \pm 0.49 \mathrm{cde}$ & $369.80 \pm 28.80 \mathrm{~h}$ \\
3 & $13.50 \pm 0.90 \mathrm{bcd}$ & $2.00 \pm 0.03 \mathrm{~b}$ & $8.85 \pm 0.19 \mathrm{abcd}$ & $6.18 \pm 0.26 \mathrm{~cd}$ & $399.95 \pm 8.10 \mathrm{~g}$ \\
4 & $13.85 \pm 0.26 \mathrm{abc}$ & $2.00 \pm 0.08 \mathrm{~b}$ & $8.77 \pm 0.97 \mathrm{bcd}$ & $5.52 \pm 0.23 \mathrm{f}$ & $401.47 \pm 9.63 \mathrm{fg}$ \\
5 & $14.02 \pm 0.70 \mathrm{ab}$ & $2.02 \pm 0.10 \mathrm{~b}$ & $8.97 \pm 0.23 \mathrm{abc}$ & $6.98 \pm 0.11 \mathrm{ab}$ & $429.25 \pm 1.27 \mathrm{~cd}$ \\
6 & $13.98 \pm 0.96 \mathrm{ab}$ & $2.01 \pm 0.06 \mathrm{~b}$ & $9.11 \pm 0.08 \mathrm{ab}$ & $6.25 \pm 0.24 \mathrm{c}$ & $421.47 \pm 12.64 \mathrm{~cd}$ \\
7 & $13.00 \pm 0.74 \mathrm{~cd}$ & $1.94 \pm 0.06 \mathrm{~b}$ & $8.27 \pm 0.06 \mathrm{~d}$ & $5.78 \pm 0.36 \mathrm{def}$ & $391.48 \pm 1.05 \mathrm{~g}$ \\
8 & $13.98 \pm 1.00 \mathrm{ab}$ & $1.99 \pm 0.11 \mathrm{~b}$ & $9.32 \pm 0.27 \mathrm{ab}$ & $7.01 \pm 0.28 \mathrm{ab}$ & $420.04 \pm 11.85 \mathrm{de}$ \\
9 & $14.70 \pm 1.01 \mathrm{a}$ & $2.18 \pm 0.14 \mathrm{a}$ & $9.42 \pm 0.19 \mathrm{a}$ & $7.23 \pm 0.07 \mathrm{a}$ & $453.02 \pm 22.02 \mathrm{a}$ \\
10 & $12.67 \pm 0.92 \mathrm{~d}$ & $1.98 \pm 0.06 \mathrm{~b}$ & $8.32 \pm 0.10 \mathrm{~d}$ & $6.18 \pm 0.17 \mathrm{~cd}$ & $358.69 \pm 12.99 \mathrm{i}$ \\
11 & $14.72 \pm 0.81 \mathrm{a}$ & $2.15 \pm 0.08 \mathrm{a}$ & $9.35 \pm 0.36 \mathrm{ab}$ & $6.72 \pm 0.22 \mathrm{~b}$ & $440.44 \pm 20.02 \mathrm{~b}$ \\
12 & $13.88 \pm 0.84 \mathrm{abc}$ & $2.02 \pm 0.09 \mathrm{~b}$ & $8.97 \pm 0.08 \mathrm{abc}$ & $6.82 \pm 0.02 \mathrm{ab}$ & $410.68 \pm 19.36 \mathrm{ef}$ \\
13 & $13.37 \pm 1.10 \mathrm{bcd}$ & $1.98 \pm 0.12 \mathrm{~b}$ & $8.40 \pm 0.41 \mathrm{~cd}$ & $6.96 \pm 0.27 \mathrm{ab}$ & $395.45 \pm 8.75 \mathrm{~g}$ \\
14 & $14.05 \pm 0.46 \mathrm{ab}$ & $2.15 \pm 0.12 \mathrm{a}$ & $9.23 \pm 0.67 \mathrm{ab}$ & $7.17 \pm 0.24 \mathrm{a}$ & $430.47 \pm 28.56 \mathrm{bc}$ \\
\hline
\end{tabular}

Different lowercase letters within a column indicate a significant difference at the 0.05 level between different treatments. Seedling height and ground diameter $(n=6)$; root length and root diameter $(n=20)$; yield $(n=3)$.
$\left.\mathrm{F}_{\mathrm{m}}\right)$ and the photochemical performance index $\left(\mathrm{PI}_{\mathrm{abs}}\right)$ of PSII. At $P<0.05, \mathrm{~F}_{\mathrm{v}} / \mathrm{F}_{\mathrm{m}}$ and $\mathrm{PI}_{\text {abs }}$ was increased by $5.23 \%$ and $163.25 \%$, respectively. The increase in $\mathrm{PI}_{\mathrm{abs}}$ was significantly greater than that of $\mathrm{F}_{\mathrm{v}} / \mathrm{F}_{\mathrm{m}}$.

Figure 3 shows the effect of fertilizer application on the energy distribution ratio of the PSII reaction center in $P$. heterophylla. At $P<$ 0.05 , the maximum quantum efficiency $(\varphi \mathrm{Po}$, $5.26 \%)$, electron transfer efficiency $\left(\Psi_{\mathrm{o}}\right.$, $20.25 \%$ ) and quantum yield of electron transfer $(\varphi \mathrm{E}, 27.20 \%)$ of PSII based on T9 were significantly greater than those of the control group (T1). The quantum ratio of heat dissipation $(\varphi \mathrm{Do})$ was significantly less than $\mathrm{T} 1$, which was decreased by $13.82 \%(P<0.05)$.

Figure 4 shows the increases in the energy of absorption (ABS/RC, 15.29\%), capture (TRo/RC, 8.14\%), and electron transfer $(\mathrm{ETo} / \mathrm{RC}, 12.33 \%)$ per unit reaction center in T9 compared with T1. The energy used for heat dissipation by unit reaction center (DIo/ RC) was decreased by $28.05 \%$ compared with that of T1. At the same time, T9 showed an increase in the density of the PSII reaction center (RC/CSo, $68.62 \%$ ) of $P$. heterophylla leaves compared with T1 $(P<0.05)$.

The relative variable fluorescence of the $L$ point and $K$ point on the OJIP curve. Significant differences were observed in the relative variable fluorescence of the $\mathrm{L}$ point $\left(\mathrm{V}_{\mathrm{L}} ; 0.15\right.$ $\mathrm{ms}$ on the standardized $\mathrm{O}-\mathrm{K}$ curve) and $\mathrm{K}$ point $\left(\mathrm{V}_{\mathrm{K}} ; 0.3 \mathrm{~ms}\right.$ on the standardized O-J curve) in $P$. heterophylla leaves between T1 (control) and T9 (with microelement fertilizers). Figure 5 illustrates the difference values of the standardized O-K and O-J curves between $\mathrm{T} 1$ and $\mathrm{T} 9$. It should be noted that the relative variable fluorescence of the $\mathrm{L}$ and $\mathrm{K}$ points was quite different in the two groups. Quantitative analysis at $P<0.05$ showed that the $\mathrm{V}_{\mathrm{L}}$ and $\mathrm{V}_{\mathrm{K}}$ of $\mathrm{T} 9$ was decreased by $15.81 \%$ and $26.33 \%$, respectively, compared with $\mathrm{T} 1$.

The relative variable fluorescence of the $J$ point and I point on the OJIP curve. After the OJIP curve was standardized by O-P (Fig. 6), $\mathrm{T} 9$ exhibited a reduction in relative variable fluorescence of the $\mathrm{J}$ point $\left(\mathrm{V}_{\mathrm{J}} ; 2 \mathrm{~ms}\right.$ on the standardized O-P curve) and I point $\left(\mathrm{V}_{\mathrm{I}} ; 30 \mathrm{~ms}\right.$ on the standardized O-P curve) of $P$. heterophylla leaves. The difference values of the standardized O-P curves of T1 and T9 showed that the reduction in $V_{J}$ was greater than that of $\mathrm{V}_{\mathrm{I}}$. The results of quantitative analysis showed that $\mathrm{V}_{\mathrm{J}}$ and $\mathrm{V}_{\mathrm{I}}$ of $\mathrm{T} 9$ decreased by $14.23 \%$ and $4.58 \%$ compared with $\mathrm{T} 1$, respectively. The change in $\mathrm{V}_{\mathrm{J}}$ was significant, but the change in $\mathrm{V}_{\mathrm{I}}$ was not obvious.

\section{Discussion}

Optimization of B, Mo, and Cu combined fertilizer in P. heterophylla. The 3414 fertilizer application experiment design, a kind of quadratic regression D-optimal design, has the advantages of low frequency treatment and high efficiency. It also meets the professional requirements of fertilizer experiments and decision making in fertilizer application and use (Ma et al., 2019; Yang et al., 2020b). 

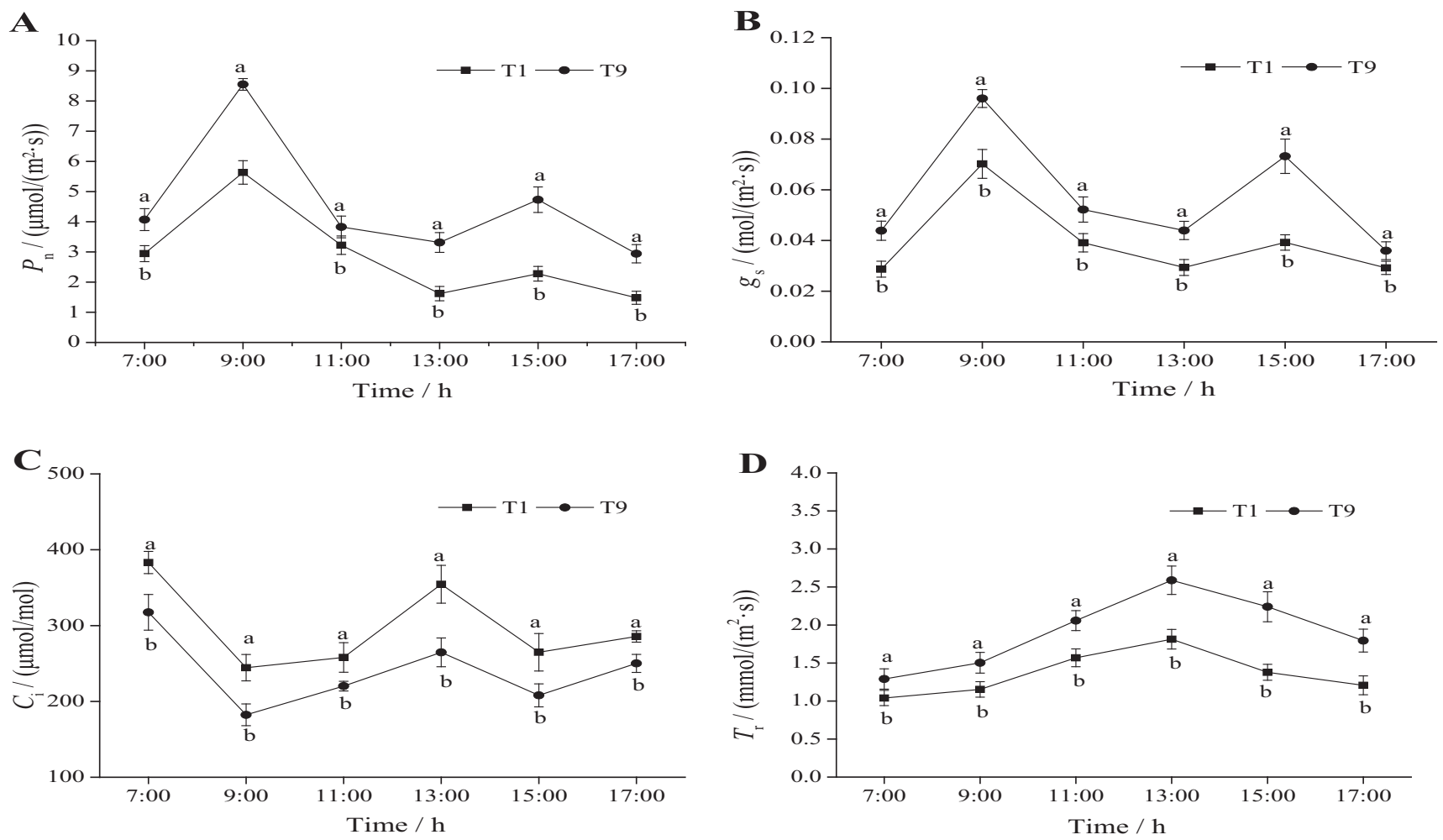

Fig. 1. Effects of the combined application of Boron (B), Molybdenum $(\mathrm{Mo})$, and Copper $(\mathrm{Cu})$ on $(\mathbf{A})$ diurnal variation of net photosynthetic rate $\left(\mathrm{P}_{\mathrm{n}}\right)$, $(\mathbf{B})$ stomatal conductance $\left(g_{\mathrm{S}}\right),(\mathbf{C})$ intercellular $\mathrm{CO}_{2}$ concentration $\left(C_{\mathrm{i}}\right)$, and $(\mathbf{D})$ and transpiration rate $\left(T_{\mathrm{r}}\right)$ in Pseudostellaria heterophylla $(\mathrm{n}=6)$. Different lowercase letters indicate significant differences between treatments $(P<0.05)$. T1 $=\mathrm{B}, 0 \mathrm{~g} \cdot \mathrm{L}^{-1} ; \mathrm{Mo}, 0 \mathrm{~g} \cdot \mathrm{L}^{-1} ; \mathrm{Cu}, 0 \mathrm{~g} \cdot \mathrm{L}^{-1} . \mathrm{T} 9=\mathrm{B}, 1 \mathrm{~g} \cdot \mathrm{L}^{-1} ; \mathrm{Mo}, 0.08$ $\mathrm{g} \cdot \mathrm{L}^{-1} ; \mathrm{Cu}, 0.05 \mathrm{~g} \cdot \mathrm{L}^{-1}$.

In recent years, the 3414 design has been gradually adapted into the practical production of medicinal plants. For example, the combined application of B-Zn-Mo 3414 effectively improved the root quality of Bupleurum chinense (Meng et al., 2014), and $\mathrm{N}-\mathrm{P}-\mathrm{K} 3414$ use showed a significant impact on the yield of Agastache rugosa (Xue et al., 2018). In addition, the 3414 fertilizer design has been tested on various types of Chinese medicinal plants, such as Panax notoginseng (Xia et al., 2016), Rheum tanguticum (Qi et al., 2015), and Atractylodes lancea (Hu et al., 2017), and showed significant effects. Therefore, the reasonable fertilizer application can provide a theoretical basis for standardized cultivation to achieve the goals of high yield and high-quality plants.
The combined application of microfertilizer is an important measure to promote plant growth and yield (Wang et al., 2020). It has the advantages of less dosage, low cost, no pollution, quick effect, and convenient operation. Different plants have different requirements and tolerances to trace elements; a toolow or too-high application dosage would affect fertilizer efficiency and even damage the soil environment. Boron, $\mathrm{Mo}$, and $\mathrm{Cu}$ are trace mineral elements necessary for plant growth and development. They participate in the regulation of photosynthesis directly or indirectly, and appropriate application could effectively increase crop yield (Faisal and Muhammad, 2019). A few studies of their application to medicinal plants have been conducted, but none have been reported on application to $P$. heterophylla. The results of our study show that the combined application of $\mathrm{B}, \mathrm{Mo}$, and $\mathrm{Cu}$ via the 3414 experimental design could significantly improve the root tuber yield of $P$. heterophylla. Our results provide an important basis for the combined $\mathrm{B}, \mathrm{Mo}$, and $\mathrm{Cu}$ fertilizer ratio toward highyield cultivation of $P$. heterophylla, and further proved the effectiveness of the 3414 experimental design.

The optimal combination of microfertilizers mainly improved the $P_{n}$ capacity of $P$. heterophylla by improving nonstomatal limitation. Analysis of diurnal variation of photosynthesis is one of the important means of exploring the effects of environmental factors on plant growth and metabolism (Lamptey et al., 2017). The characteristic parameters of
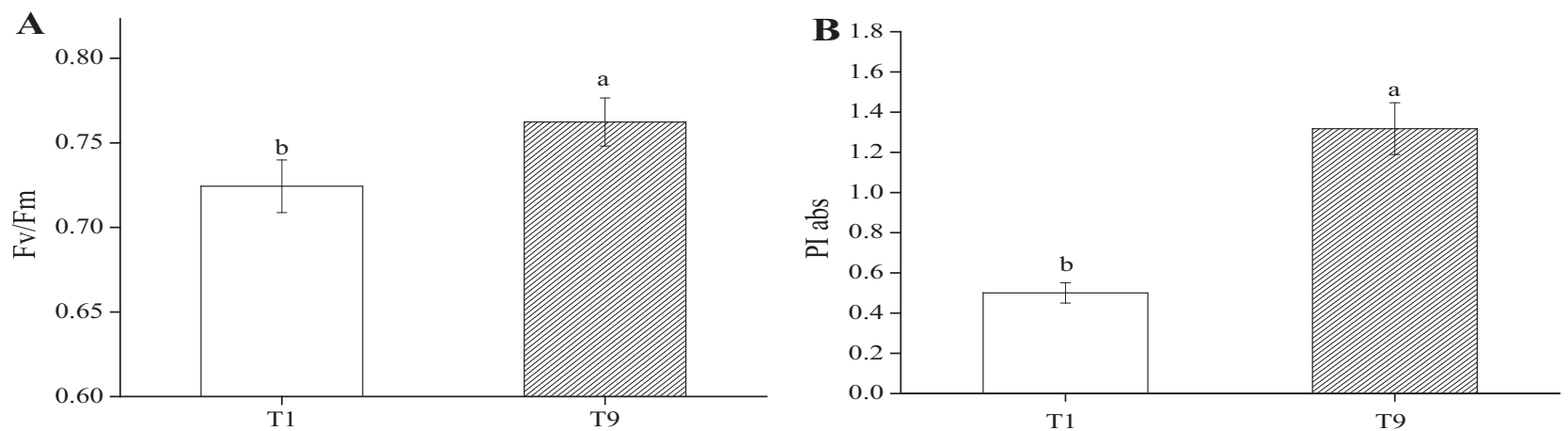

Fig. 2. Effects of the combined application of Boron (B), Molybdenum (Mo), and Copper $(\mathrm{Cu})$ on the maximum photochemical efficiency of PSII ( $\left.\mathrm{F}_{\mathrm{v}} / \mathrm{F}_{\mathrm{m}}\right)$ and the photochemical performance index (PIabs) in $P$. heterophylla. Different lowercase letters indicate significant differences between treatments $(P<0.05 ; \mathrm{n}=6) . \mathrm{T} 1=\mathrm{B}, 0 \mathrm{~g} \cdot \mathrm{L}^{-1} ; \mathrm{Mo}, 0 \mathrm{~g} \cdot \mathrm{L}^{-1} ; \mathrm{Cu}, 0 \mathrm{~g} \cdot \mathrm{L}^{-1} . \mathrm{T} 9=\mathrm{B}, 1 \mathrm{~g} \cdot \mathrm{L}^{-1} ; \mathrm{Mo}, 0.08 \mathrm{~g} \cdot \mathrm{L}^{-1} ; \mathrm{Cu}, 0.05 \mathrm{~g} \cdot \mathrm{L}^{-1}$. 


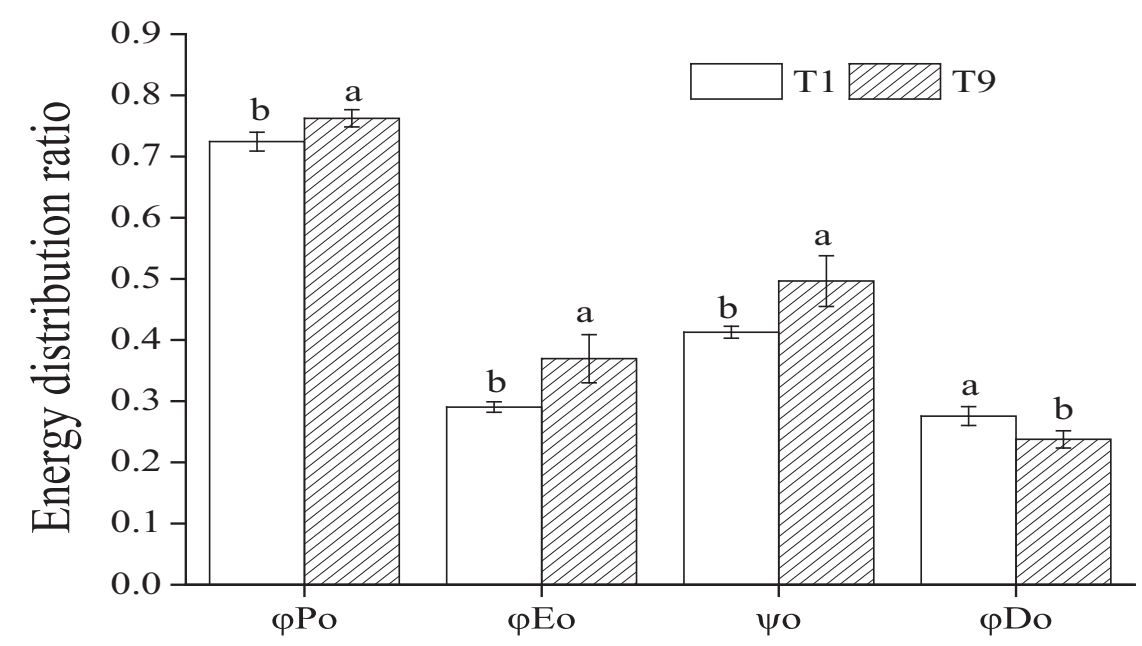

Fig. 3. Effects of the combined application of Boron (B), Molybdenum (Mo), and Copper $(\mathrm{Cu})$ on the energy distribution ratio of the photosystem II (PSII) reaction center in P. heterophylla. Different lowercase letters indicate significant differences between treatments $(P<0.05 ; \mathrm{n}=6$. T1 $=\mathrm{B}, 0$ $\mathrm{g} \cdot \mathrm{L}^{-1} ; \mathrm{Mo}, 0 \mathrm{~g} \cdot \mathrm{L}^{-1} ; \mathrm{Cu}, 0 \mathrm{~g} \cdot \mathrm{L}^{-1}$. T9 = B, $1 \mathrm{~g} \cdot \mathrm{L}^{-1} ; \mathrm{Mo}, 0.08 \mathrm{~g} \cdot \mathrm{L}^{-1} ; \mathrm{Cu}, 0.05 \mathrm{~g} \cdot \mathrm{L}^{-1}$.

diurnal variation of photosynthesis reflect the continuous ability of material accumulation and physiological metabolism of plants in a day. More importantly, they help when determining and analyzing the limiting factors in photosynthesis (Liu et al., 2019). Our study showed that the diurnal variation of $\mathrm{P}_{\mathrm{n}}$ in $P$. heterophylla leaves had an obvious photosynthetic midday depression in the current environmental conditions, when the local temperature had not yet reached a high in mid-May. This indicates that $P$. heterophylla has poor tolerance to high temperatures and strong light. This result is in accordance with the characteristics of $P$. heterophylla's preference for a cool environment under natural growth conditions. During the photosynthetic midday depression period, $\mathrm{P}_{\mathrm{n}}$ and $g_{\mathrm{S}}$ of $\mathrm{T} 1$ (control) decreased significantly, whereas $C_{\mathrm{i}}$ increased significantly, indicating that the decrease in $P_{n}$ capacity was caused mainly by nonstomatal factors (Farquhar and Sharkey, 1982). When compared with T1, T9 (the optimized treatment) did not change the bimodal variation trend of $P$. heterophylla $\mathrm{P}_{\mathrm{n}}$, but increased $\mathrm{P}_{\mathrm{n}}$ and $g_{\mathrm{S}}$, and decreased $C_{\mathrm{i}}$ during the photosynthetic midday depression period. Our results indicate that the applied combined fertilizer alleviated the photosynthetic midday depression of $P$. heterophylla leaves by improving nonstomatal factors. At the same time, judging from the diurnal variation of photosynthesis throughout the whole day, T9 showed a significant increase in the daily mean of $\mathrm{P}_{\mathrm{n}}$ and $g_{\mathrm{S}}$, whereas $C_{\mathrm{i}}$ was decreased significantly. Our results also show that the optimal combination of micronutrient fertilizer promoted the $\mathrm{P}_{\mathrm{n}}$ capacity of $P$. heterophylla by improving nonstomatal limitation throughout the day.

The optimal combination of microfertilizers improved PSII photochemical activity and alleviated photoinhibition. PSII is the primary and main part of photoinhibition when plants are exposed to high temperatures, strong light, and other environmental stresses (Yu et al., 2020). In the light reaction system, PSII is affected more easily by the internal and external environment than photosystem I. Because the JIP test can analyze the functional state and specific information of each part in the primary photochemical reaction process of PSII quickly and nondestructively, it was suitable for exploring further the mechanism of improving the nonstomatal limitation of $P$. heterophylla by combined application of microfertilizers.
Both $\mathrm{F}_{\mathrm{v}} / \mathrm{F}_{\mathrm{m}}$ and $\mathrm{PI}_{\mathrm{abs}}$ are important indicators of plant photoinhibition (Kalaji et al., 2016). $F_{\mathrm{v}} / F_{\mathrm{m}}$ was about 0.8 when plants grew normally. In our study, the $\mathrm{F}_{\mathrm{v}} / \mathrm{F}_{\mathrm{m}}$ value of $P$. heterophylla in $\mathrm{T} 1$ was significantly less than 0.75 , indicating that PSII had photoinhibition. This observation further proved that $P$. heterophylla was not resistant to strong light and high temperatures. Compared with $\mathrm{T} 1$, plant leaves in $\mathrm{T} 9$ showed a significant increase in $\mathrm{F}_{\mathrm{v}} / \mathrm{F}_{\mathrm{m}}$ and $\mathrm{PI}_{\mathrm{abs}}$. T9 also demonstrated a significant increase in the maximum $\mathrm{P}_{\mathrm{n}}$ rate (peak value) and the valley value at the midday depression (Fig. 1). These results indicate that the combined fertilizers applied alleviated the photoinhibition of $P$. heterophylla leaves and improved its photosynthetic performance.

The results of energy distribution ratio parameters $\left(\varphi \mathrm{Po}, \Psi_{\mathrm{o}}, \varphi \mathrm{E} o\right.$, and $\left.\varphi \mathrm{Do}\right)$ in $\mathrm{T} 9$ showed an increase in the absorption and capture of light energy and the energy ratio for electron transfer of PSII, but a decrease in the heat dissipation ratio. Thus, plants in $\mathrm{T} 9$ enhanced the photochemical activity of PSII and alleviated photoinhibition by enhancing the photochemical utilization of light energy, rather than by heat dissipation. The results of specific activity parameters (ABS/RC, TRo/ $\mathrm{RC}, \mathrm{ETo} / \mathrm{RC}$, and $\mathrm{DIo} / \mathrm{RC}$ ) and density parameters $(\mathrm{RC} / \mathrm{CSo})$ of the PSII reaction center further shows that the microfertilizers applied enhanced the activity of the PSII unit reaction center, and increased the number of reaction centers per unit area of leaves, thus improving the photochemical activity of PSII in whole leaves.

The photochemical activity of the PSII reaction center was reflected mainly in the electron transfer efficiency of PSII. This is related primarily to the electron supply capacity of the PSII electron donor side and the electron transfer capacity of the PSII electron acceptor side (Jedmowski and Brueggemann, 2015; Khoshbakht et al., 2018). The change in relative variable fluorescence at the inflection point in the OJIP curve is helpful to analyze further the electron transport of PSII and to explore the mechanism of enhancing the photochemical activity of $P$. heterophylla by foliar microfertilizer application. The increase in $\mathrm{K}$ point relative variable fluorescence on the OJIP curve is a specific marker of the
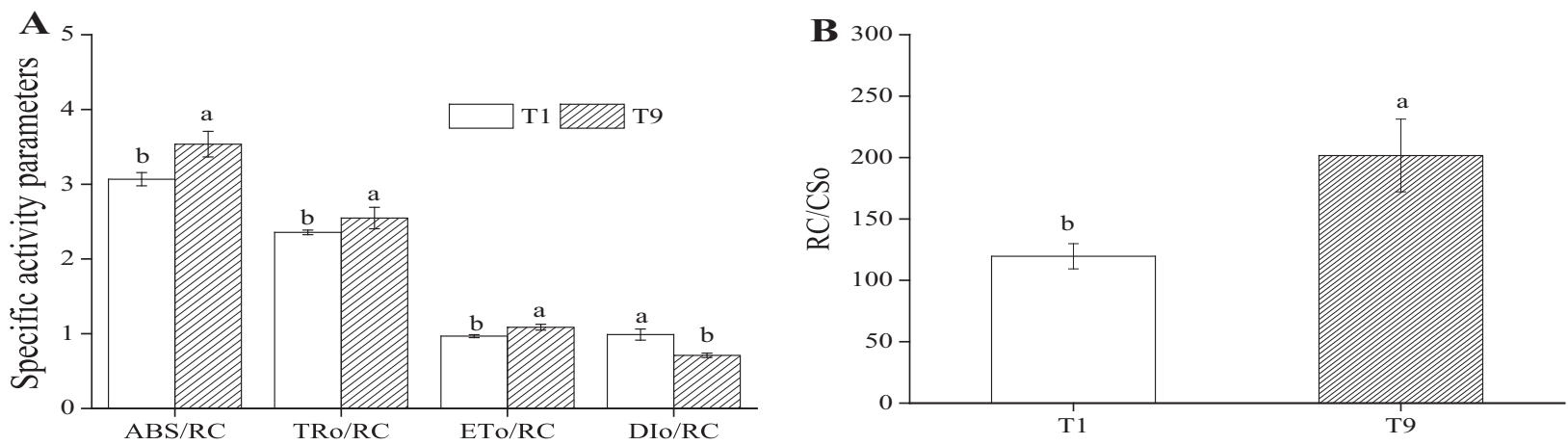

Fig. 4. Effects of the combined application of Boron (B), Molybdenum (Mo), and Copper $(\mathrm{Cu})$ on the specific activity parameters and density of the photosystem II (PSII) reaction center in $P$. heterophylla. Different lowercase letters indicate significant differences between treatments $(P<0.05 ; \mathrm{n}=6)$. T1 $=$ $\mathrm{B}, 0 \mathrm{~g} \cdot \mathrm{L}^{-1} ; \mathrm{Mo}, 0 \mathrm{~g} \cdot \mathrm{L}^{-1} ; \mathrm{Cu}, 0 \mathrm{~g} \cdot \mathrm{L}^{-1} \cdot \mathrm{T} 9=\mathrm{B}, 1 \mathrm{~g} \cdot \mathrm{L}^{-1} ; \mathrm{Mo}, 0.08 \mathrm{~g} \cdot \mathrm{L}^{-1} ; \mathrm{Cu}, 0.05 \mathrm{~g} \cdot \mathrm{L}^{-1}$. 

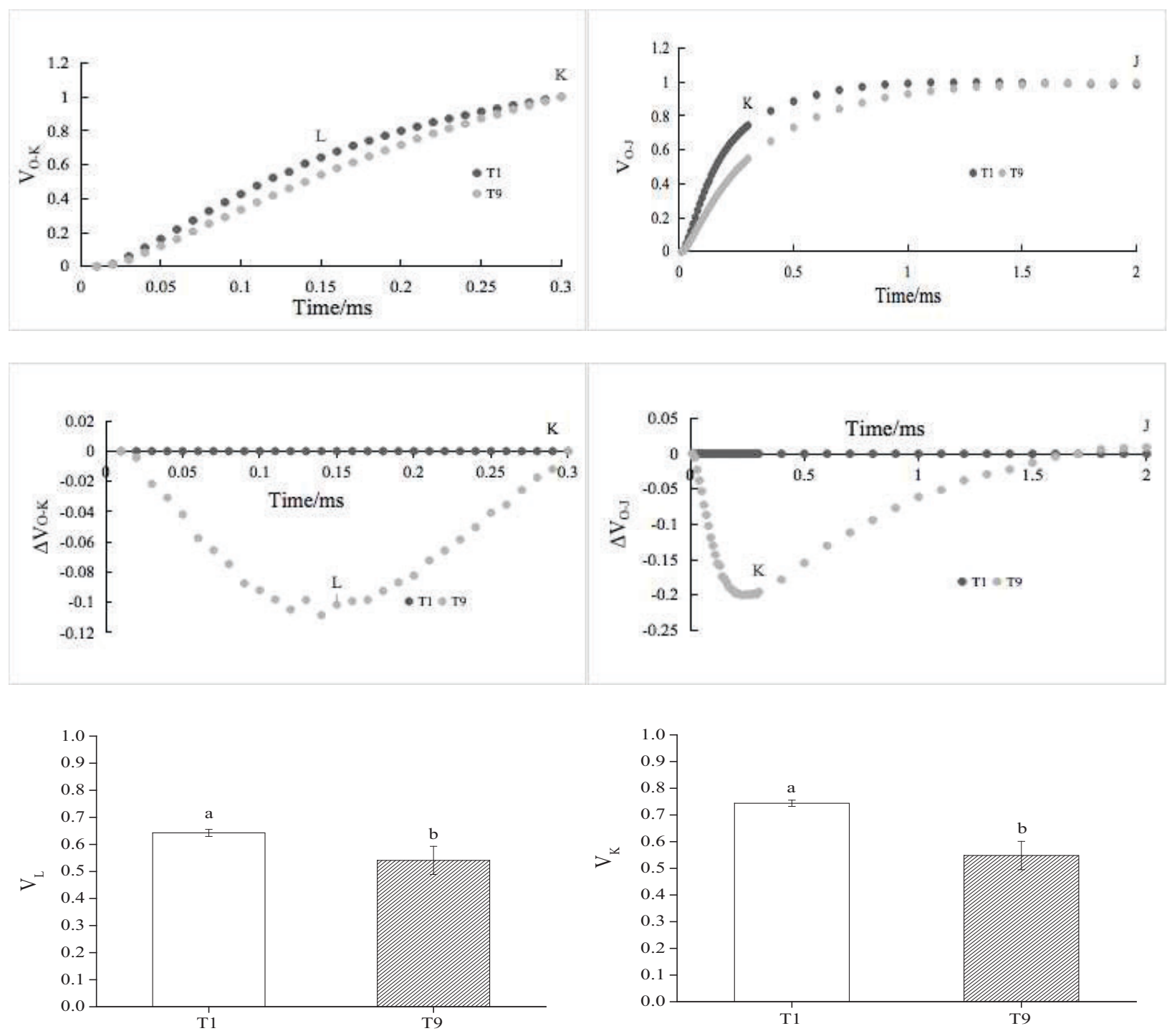

Fig. 5. Effects of the combined application of Boron (B), Molybdenum (Mo), and Copper (Cu) on the standardized O-K and O-J curves in $P$. heterophylla leaves. Different lowercase letters indicate significant differences between treatments $(P<0.05 ; \mathrm{n}=6)$. T1 $=\mathrm{B}, 0 \mathrm{~g} \cdot \mathrm{L}^{-1} ; \mathrm{Mo}, 0 \mathrm{~g} \cdot \mathrm{L}^{-1} ; \mathrm{Cu}, 0 \mathrm{~g} \cdot \mathrm{L}^{-1}$. T9 $=\mathrm{B}, 1 \mathrm{~g} \cdot \mathrm{L}^{-1}$; $\mathrm{Mo}, 0.08 \mathrm{~g} \cdot \mathrm{L}^{-1} ; \mathrm{Cu}, 0.05 \mathrm{~g} \cdot \mathrm{L}^{-1}$.

damage to the oxygen-evolving complex (OEC). As OEC activity is inhibited, the water-splitting function becomes disordered and a large amount of $\mathrm{H}_{2} \mathrm{O}_{2}$ is produced in the chloroplasts. $\mathrm{H}_{2} \mathrm{O}_{2}$ aggravates the oxidative damage of chloroplast membrane lipids and increases membrane permeability. With the increase of membrane lipid peroxidation in the chloroplasts, membrane lipids and membrane proteins are free to form an osmiophilic body-namely, liposome. The formation of liposomes results from degradation and aggregation of chloroplast thylakoids, and the rise of the $\mathrm{L}$ point relative variable fluorescence $(0.15 \mathrm{~ms})$ on the OJIP curve is a specific marker of thylakoid dissociation. Absorption, transmission, and transformation of light energy by plant leaves are carried out on the thylakoid membrane of chloroplast, and the PSII protein complex is embedded directly in the thylakoid membrane. Therefore, the destruction of PSII function is related directly to the dissociation of thylakoid. The $\mathrm{V}_{\mathrm{L}}$ and $\mathrm{V}_{\mathrm{K}}$ of $P$. heterophylla leaves were decreased significantly in $\mathrm{T} 9$, suggesting that microfertilizer application could protect OEC activity to reduce oxidative damage to the chloroplasts, prevent dissociation of thylakoid, and increase the tight connection between protein subunits in the PSII complex to maintain the normal physiological function of PSII and reduce the degree of photoinhibition (Hao et al., 2019). The relative variable fluorescence of the $\mathrm{J}$ point on the OJIP curve represents the number of closed reaction centers or the reduced amount of $\mathrm{Q}_{\mathrm{A}}$. $\mathrm{Q}_{\mathrm{A}}$ is often reduced excessively and $\mathrm{Q}_{\mathrm{A}}{ }^{-}$accumulates greatly under adverse conditions - namely, $\mathrm{V}_{\mathrm{J}}$ tends to increase (Zhang et al., 2015b). The accumulation of $\mathrm{Q}_{\mathrm{A}}^{-}$is a result of the inhibition of the electron transfer from $\mathrm{Q}_{\mathrm{A}}^{-}$to $\mathrm{Q}_{\mathrm{B}}$ after pheophytin transfers electrons to $\mathrm{Q}_{\mathrm{A}}$ to produce $\mathrm{Q}_{\mathrm{A}}^{-}$(Zhang et al., 2015b). Therefore, the increase in $\mathrm{V}_{\mathrm{J}}$ is also a specific indicator that the electron transfer from $\mathrm{Q}_{\mathrm{A}}$ to $\mathrm{Q}_{\mathrm{B}}$ on the PSII receptor side is blocked. In our study, the foliar microfertilizer treatment (T9) reduced the $\mathrm{V}_{\mathrm{J}}$ of $P$. heterophylla leaves, suggesting that elements from the microfertilizers could relatively increase the electron transfer capacity of $\mathrm{Q}_{\mathrm{A}}$ to $\mathrm{Q}_{\mathrm{B}}$ on the PSII receptor side. The change in the relative variable fluorescence of I point at $30 \mathrm{~ms}$ reflects the heterogeneity of the PQ pool during the electron transfer from $Q_{A}$ to $Q_{B}$ (Strasser, 1997). The microfertilizer application reduced the $\mathrm{V}_{\mathrm{I}}$ of $P$. heterophylla leaves, suggesting that microfertilizers could increase the ability of the PQ pool to accept electrons, which is also one of the reasons for promoting the electron transfer from $\mathrm{Q}_{\mathrm{A}}{ }^{-}$to $\mathrm{Q}_{\mathrm{B}}$. The microfertilizer treatment both increased the electron supply capacity of the PSII donor side and the electron transfer capacity of the PSII receptor side, and especially protected the activity of OEC effectively on the donor side.

\section{Conclusion}

Our results show that the 3414 experimental design helped optimized the combined microfertilizer ratio of $\mathrm{B}, \mathrm{Mo}$, and $\mathrm{Cu}$ for application on the leaf surface of $P$. heterophylla. We also demonstrated that microfertilizer application can promote the growth of $P$. 

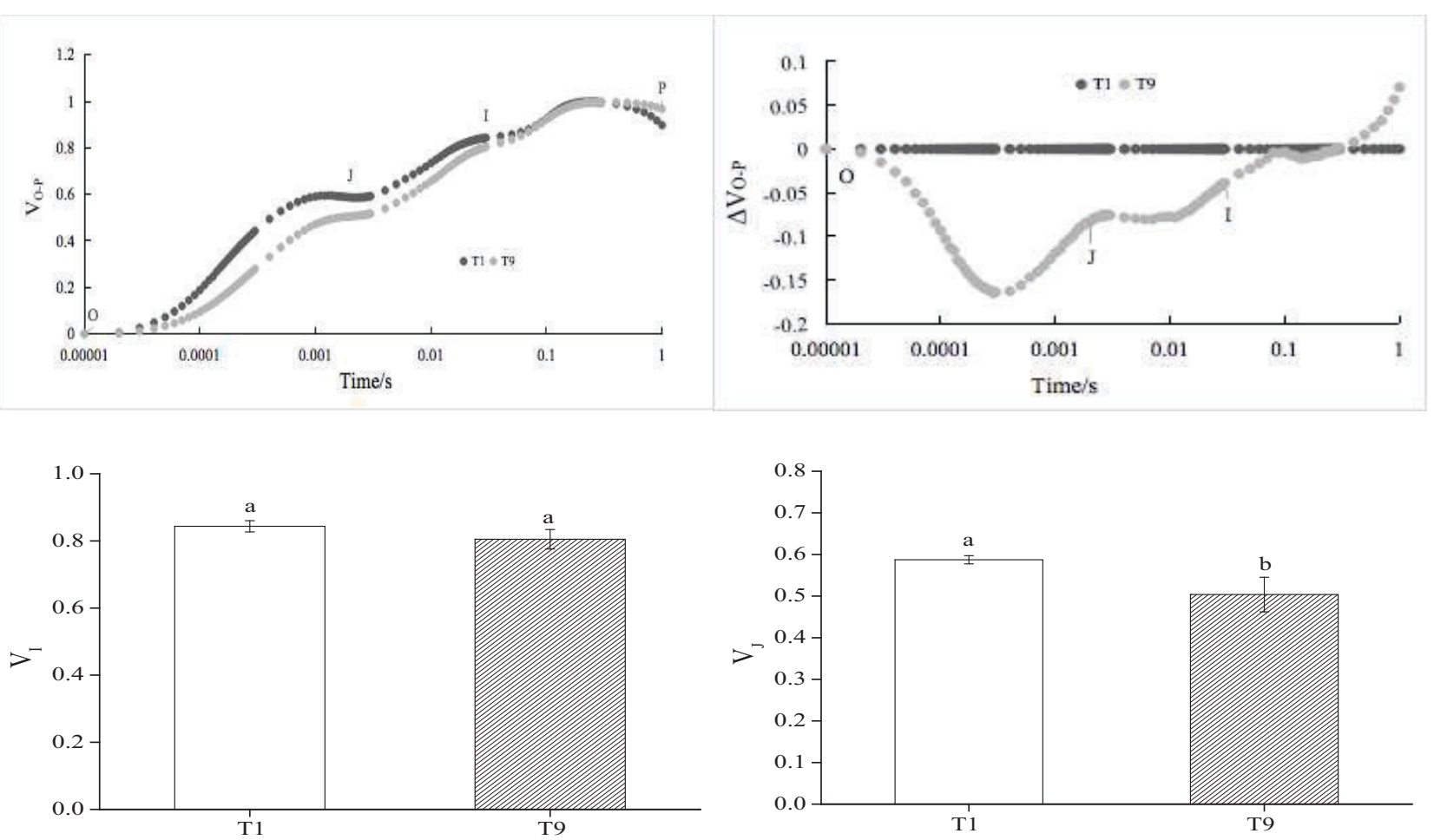

Fig. 6. Effects of the combined application of Boron (B), Molybdenum (Mo), and Copper $(\mathrm{Cu})$ on the standardized O-P curve in P. heterophylla leaves. Different lowercase letters indicate significant differences between treatments $(P<0.05 ; \mathrm{n}=6)$. T1 $=\mathrm{B}, 0 \mathrm{~g} \cdot \mathrm{L}^{-1} ; \mathrm{Mo}, 0 \mathrm{~g} \cdot \mathrm{L}^{-1} ; \mathrm{Cu}, 0 \mathrm{~g} \cdot \mathrm{L}^{-1}$. T9 $=\mathrm{B}, 1 \mathrm{~g} \cdot \mathrm{L}^{-1}$; Mo, $0.08 \mathrm{~g} \cdot \mathrm{L}^{-1} ; \mathrm{Cu}, 0.05 \mathrm{~g} \cdot \mathrm{L}^{-1}$.

heterophylla significantly and increase its root tuber yield per unit area. Moreover, the use and application of the optimal ratio of microfertilizers enhanced the $P_{n}$ capacity significantly during the process of diurnal variation of photosynthesis by improving nonstomatal limitation.

Optimal application of combined B, Mo, and $\mathrm{Cu}$ fertilizers promoted the absorption, capture, and conversion of light energy and efficiency of electron transfer by $P$. heterophylla PSII, and alleviated the photoinhibition caused by excess excitation energy. The stability in structure and function of OEC on donor side of PSII, the enhancement of electron transfer ability of $\mathrm{Q}_{\mathrm{A}}$ to $\mathrm{Q}_{\mathrm{B}}$ on receptor side, and the increased number of reaction centers per unit area might be the main mechanisms for enhancing photochemical activity of PSII and improving photosynthetic performance of $P$. heterophylla leaves. The results of this study provided an important basis for the ratio of $\mathrm{B}$, $\mathrm{Mo}$, and $\mathrm{Cu}$ fertilizers to use and apply toward high-yield cultivation and its physiological mechanism in $P$. heterophylla.

\section{Literature Cited}

Faisal, N. and F. Muhammad. 2019. Application of micronutrients in rice-wheat cropping system of South Asia. Rice Sci. 26:356-371, doi: https://doi.org/10.1016/j.rsci.2019.02.002.

Farquhar, G.D. and T.D. Sharkey. 1982. Stomatal conductance and photosynthesis. Annu. Rev. Plant Physiol. 33:317-345, doi: https://doi.org/ 10.1146/annurev.pp.33.060182.001533.

Hao, X.C., S. Zhou, Y. Zhai, and L.J. Han. 2019. Influence of temperature stress on photosystem of Nothofagus antarctica. J. Central South
Univ. For. Technol.. 39:1-7, doi: https://doi. org/10.14067/j.cnki.1673-923x.2019.09.001.

Hu, Y.W., J.G. Chao, and M.Y. Li. 2017. Effects on the yield and quality of Atractylodes lancea by using ' 3414 ' fertilization scheme. Res. Pract. Chinese Med. 4:5-8, doi: https://doi.org/ 10.13728/j.1673-6427.2017.04.001.

Jedmowski, C. and W. Brueggemann. 2015. Imaging of fast chlorophyll fluorescence induction curve (OJIP) parameters, applied in a screening study with wild barley (Hordeum spontaneum) genotypes under heat stress J. Photochem. Photobiol. B 151:153-160, doi: https://doi.org/ 10.1016/j.jphotobiol.2015.07.020.

Kalaji, H.M., A. Jajoo, A. Oukarroum, M. Brestic, M. Zivcak, I.A. Samborska, M.D. Cetner, I. Lukasik, V. Goltsev, and R.J. Ladle. 2016. Chlorophyll a fluorescence as a tool to monitor physiological status of plants under abiotic stress conditions. Acta Physiol. Plant. 38:1-11, doi: https://doi.org/10.1007/s11738-016-2113-y.

Khoshbakht, D., M.R. Asghari, and M. Haghighi. 2018. Effects of foliar applications of nitric oxide and spermidine on chlorophyll fluorescence, photosynthesis and antioxidant enzyme activities of citrus seedlings under salinity stress. Photosynthetica 56:1313-1325, doi: https://doi org/10.1007/s11099-018-0839-z.

Lamptey, S., L.L. Li, J.H. Xie, R.Z. Zhang, S. Yeboah, and D.L. Antille. 2017. Photosynthetic response of maize to nitrogen fertilization in the semiarid western Loess Plateau of China Crop Sci. 57:2739-2752, doi: https://doi.org/ 10.2135/cropsci2016.12.1021

Li, C.X. 2019. Effects and mechanism of seed soaking and foliar spraying of manganese, iron and molybdenum on growth and absorb of Wheat. Northwest A\&F University, Shanxi, China.

Liu, J.J., X.P. Wang, Y.F. Gao, Z.L. Rong, G.D. Zhang, W.B. Wang, J. Ge, Y.H. Mao, Z.X Guo, and C. Zhao. 2019. Leaf gas exchange and photosynthesis curves of Elymus nutans and Potentilla anserina under fencing and grazing conditions in the Qilian Mountains, Northwest China. J. Arid Land 11:431-445, doi: https://doi.org/10.1007/s40333-019-0009-6.

Ma, L.Z., T.C. Duan, and J.D. Hu. 2019. Application of a universal soil extractant for determining the available NPK: A case study of crop planting zones in central China. Sci. Total Environ. 704:135253, doi: https://doi.org/10.1016/ j.scitotenv.2019.135253.

Ma, Y.L., H.C. Zou, H. Gu, D.W. Shi, W.X. Gao, Y.F. Zhang, and Y.F. Xie. 2017. Stimulatory effect of lanthanum nitrate on the root tuber yield of Pseudostellaria heterophylla via improved photosynthetic characteristics. J. Rare Earth 35:610-620, doi: https://doi.org/10.1016/S10020721(17)60954-2.

Macedo, L.O., D. Mattos, R. Jacobassi, F.W.R. Hippler, J.A. Quaggio, and R.M. Boaretto 2021. Efficiency of foliar application of sparingly soluble sources of boron and zinc in citrus. Sci. Agr. 78(1):e20180387, doi: https://doi. org/10.1590/1678-992X-2018-0387.

Meng, J., X.F. Chen, W.Y. Yang, Z.F. Li, Y. Zhang, J.H. Song, and X.W. Yang. 2014. Effect of combined application of zinc, boron and molybdenum on yield and saikosaponin a, saikosaponin d contents of Bupleurum chinense. China J. Chinese Materia Medica 22:4297-4303, doi: https:// doi.org/10.4268/cjcmm20142205.

Mo, S.L. 2018. Effects of copper fertilizer on rice yield. Agr. Res. Appl. 31:23-25, doi: https:// doi.org/CNKI:SUN:GXRZ.0.2018-03-005.

Qi, H., Y. Chen, F.X. Guo, S. Cao, Z.J. Guo, and Y.F. Yang. 2015. Use of the '3414' fertilization design to determine optimal fertilization rates for Rheum tanguticum. Acta Prataculturae Sinica 24:19-29, doi: https://doi.org/10.11686/ cyxb2014409.

Song, B.Q., Z.Z. Wu, X.Y. Zhao, Z.S. Yan, K.X. Li, X.L. Liang, and T.X. Zhu. 2019. Effect of leaf spraying boron on leaf properties and root quality in sugar beet. Sugar Crops China 41:50-53, doi: https://doi.org/CNKI:SUN:ZGTI.0.2019-04-010. 
Strasser, B.J. 1997. Donor side capacity of photosystem II probed by chlorophyll A fluorescence transients. Photosynth. Res. 52:147-155.

Sun, H., K. Shi, and K. Qi. 2010. Pseudostellaria heterophylla extract polysaccharide H-1-2 suppresses pancreatic cancer by inhibiting hypoxiainduced anterior gradient 2. Mol. Ther. Oncolytics 17:61-69, doi: https://doi.org/10.1016/j. omto.2020.03.007.

Verbruggen, N. and C. Hermans. 2013. Physiological and molecular responses to magnesium nutritional imbalance in plants. Plant Soil 368:87-99, doi: https://doi.org/10.1007/s11104-013-1589-0.

Wang, F.H., Y. Li, Y. Jiang, S.C. Chen, S.X. Wang, B.G. Liu, and L.Yang. 2018. The effects of boric acid on the flowering physiological metabolism and affinity of self-incompatibility radish during reproductive growth. Soil Fert. China 3:149-154, doi: https://doi.org/10.11838/sfsc.20180323.

Wang, R.R., J. Huang, A.C. Liang, Y. Wang, L.A.J. Mur, M. Wang, and S.W. Guo. 2020. Zinc and copper enhance cucumber tolerance to fusaric acid by mediating its distribution and toxicity and modifying the antioxidant system. Intl. J. Mol. Sci. 21:3370, doi: https://doi.org/10.3390/ ijms21093370.
Wu, X.W., M. Riaz, L. Yan, C.Q. Du, Y.L. Liu, and C.C. Jiang. 2017a. Boron deficiency in trifoliate orange induces changes in pectin composition and architecture of components in root cell walls. Front. Plant Sci. 8:1882-1891, doi: https://doi.org/10.3389/fpls.2017.01882.

Wu, Y.X., H.Q. Wang, S.Y. Shen, Y. Lian, Z.Z. Long, T.Y. He, J.D. Rong, and Y.S. Zheng. 2017b. Effects of different fertilization schemes on active components of Pseudostellaria heterophylla. Jiangsu Agr. Sci. 45:140-143, doi: https:// doi.org/10.15889/j.issn.1002-1302.2017.06.036.

Xia, P.G., H.B. Guo, H.G. Zhao, J. Jiao, M.K. Deyholos, X.J. Yan, Y. Liu, and Z.S. Liang. 2016. Optimal fertilizer application for Panax notoginseng and effect of soil water on root rot disease and saponin contents. J. Ginseng Res. 40:38-46, doi: https://doi.org/10.1016/j.jgr.2015.04.003.

Xue, Q., K.C. Wang, L. Sui, Y.F. Liang, Y.Y. Su, and J.W. Yang. 2018. Effects of combined application of $\mathrm{N}, \mathrm{P}$ and $\mathrm{K}$ on growth and yield of Agastache rugosa. J. Chinese Med. Materials 41:28-33, doi: https://doi.org/10.13863/j. issn100-4454.2018.04.004.

Yang, Q., X.X. Cai, M.C. Huang, and S.Y. Wang. 2020a. A specific peptide with immunomodulatory activity from Pseudostellaria heterophylla and the action mechanism. J. Funct. Foods 68 : 103887, doi: https://doi.org/10.1016/j.jff.2020. 103887.

Yang, Z.J., X.H. Wu, S.C. Grossnickle, L.H. Chen, X.X. Yu, Y.A. El-Kassaby, and J.L. Feng. 2020b. Formula fertilization promotes Phoebe bournei robust seedling cultivation. Forests 11:781, doi: https://doi.org/10.3390/f11070781.

Yu, T.L., W.X. Wei, Z.R. Bai, Z. Bin, J.W. Zhang, P. Liu, and S.Z. Zi. 2020. High temperature reduces photosynthesis in maize leaves by damaging chloroplast ultrastructure and photosystem II. J. Agron. Crop Sci. 206:548-564, doi: https://doi.org/10.1111/jac.12401.

Zhang, L.W., X. Wei, X.Y. Wang, Z. Zhao, and Z. Li. 2015a. Effects of different fertilization treatments on growth, root rot and yield of Pseudostellaria heterophylla. Jiangsu Agr. Sci. 43:236-238, doi: https://doi.org/10.15889/jissn. 1002-1302.2015.05.078.

Zhang, X.L., Q.Q. Zhang, T.X. Xu, F. Ling, and G.Y. Sun. 2015b. Amelioration of chemical and organic fertilizer on photo-inhibition of PSII at photosynthetic noon-break in mulberry leaves grew in saline-sodic soils. Pratacultural Sci. 32: 745-753, doi: https://doi.org/10.11829 j.isn.10 01-0629.2014-0428. 